\title{
Defence physicist
} takes on top post at Australia's CSIRO

Sydney \& London. Malcolm McIntosh, chief of defence procurement in the UK Ministry of Defence, is to return home to Australia to head the troubled government science agency, the Commonwealth Scientific and Industrial Research Organisation (CSIRO).

But as McIntosh cannot take up the \$A200,000-a-year (US\$145,000) appointment until the beginning of next year - and to allow efforts to continue the search for solutions to the CSIRO's recent well-publicized internal problems - Peter Cook, the Minister for Industry, Science and Technology, has taken the unusual step of appointing the organization's acting chief executive, Roy Green, as chief executive officer.

McIntosh, who is 49 , holds a $\mathrm{PhD}$ in physics from the Australian National University, and started his career as a research scientist in the Australian Weapons Research Establishment. He has held his current post in the United Kingdom for five years, dealing with a number of politically charged decisions that have included negotiations over the purchase of Chinook helicopters and, most recently, restructuring the Eurofighter programme.

Before taking up that post, he was the most senior civil servant in Australia's Department of Industry, Trade and Commerce. He was chosen from a shortlist of 14 candidates, and says of the CSIRO that "clearly the institution is all about excellence in science, and I would want to see it compete with the best in the world".

But McIntosh remains discreet about his views on current problems within the organization - in particular those arising from communication difficulties between management and staff (see Nature 372, 585; 1995) - saying "I do not at present know enough to be able to comment on how to solve them".

Green has been the CSIRO's acting chief executive since the departure of the former chief executive, John Stocker, in March. As such, he has had to deal with revelations about the poor state of the organization, as well as discontent among its scientists.

Green had previously said that any major changes to the organization - such as the recommended removal of a layer of management - would have to await the arrival of its new chief executive. He had been due to retire in November, but will now remain until McIntosh arrives.

CSIRO's problems were recently highlighted by an incident in which five senior executives were virtually forced to read out a letter of apology over the wording of a submission made by their staff to the board.

Mark Lawson \& David Dickson

\section{Breeder plans are dented as thermal reactor support falls}

Tokyo. Japan's electric power companies have decided to drop their support for construction of an advanced thermal reactor (ATR), a move which may deal a fatal blow to plans to build commercial fast breeder reactors (FBRs) in the early decades of the next century.

On 11 July, the nine members of the Federation of Electric Power Companies asked the government to scrap a long-standing plan to build a demonstration ATR, intended to pave the way for commercial FBRs. The reactor was to have been built in Ohma, in Aomori Prefecture, at the northern tip of Japan's main island of Honshu.

According to the federation, soaring costs for the proposed 606-MW ATR have made the project commercially unviable. The original cost estimate was $¥ 396$ billion (US $\$ 4.56$ billion) in 1984, compared to the latest government estimate of $¥ 580$ billion.

Instead of an ATR, the members of the federation now propose building a much

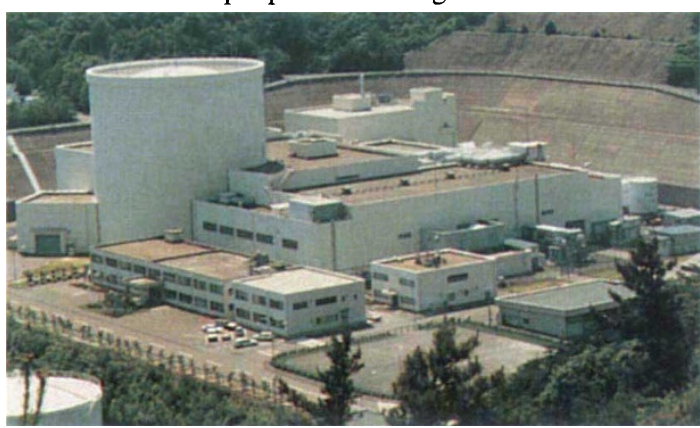

Fugen reactor: this prototype now seems unlikely to be followed by full-scale advanced thermal nuclear station.

cheaper conventional light-water reactor at Ohma. This would have more than twice the power of the proposed ATR, and would fulfil the same role of burning up some of Japan's growing stockpile of plutonium derived from reprocessed fuel.

Officials of the Ministry of International Trade and Industry (MITI) and the Science and Technology Agency (STA) have been trying to play down the significance of the federation's announcement. They say that the fate of the ATR will be decided by the Atomic Energy Commission, not by the electricity industry.

But last week, Makiko Tanaka, the outspoken female politician who heads the STA and chairs the commission, effectively killed the ATR by announcing at a press conference it is "only natural" that industry should pursue profits. "Even if the Atomic Energy Commission and the STA discuss the matter, I don't expect the federation to change its mind," Tanaka said. Without industry's support the project cannot proceed.

The ATR project was launched by the commission nearly thirty years ago in 1966 as part of an overall strategy leading to the development of FBRs. The reactor, which uses heavy water as a moderator and a mixed uranium-plutonium fuel, was intended to consume part of Japan's growing stockpile of plutonium before the introduction of commercial fast breeders, scheduled to take place around 2030. Construction of the ATR was due to begin in 1998, and it was to have come into operation in 2004.

Nearly $¥ 300$ billion has already been invested by the government and industry in developing the ATR over the past three decades. This figure includes $¥ 68$ billion spent on constructing a prototype, named Fugen, that has been in commercial operation since 1979 (see picture). In the current fiscal year alone, nearly $¥ 5$ billion has been set aside for the ATR project by the STA.

But the Federation of Electric Power Companies estimates that electricity from the Ohma demonstration reactor would cost $¥ 38$ a kilowatt, three times as much as that produced by a conventional light-water reactor. With the government planning to deregulate the electric power industry from next year, the industry felt it could not continue to support the project. Furthermore, new technology means that light-water reactors can now burn mixed plutonium-uranium fuel, and the ATR has therefore lost its main purpose.

STA officials claim that abandoning the ATR would not directly affect the development of FBRs. Indeed, FBRs are not dependent on ATRs in a technical sense. But industry observers say the federation's decision suggests that the electric power industry is unlikely to support the development of commercial FBRs, which are more expensive to build and operate than ATRs.

David Swinbanks

\section{Biotech tax set-back}

London. Britain's Secretary of State for Health has refused to support pleas from the biotechnology industry for special tax status. In an interview with the Financial Times, Stephen Dorrell said he supported investment in these fields. But he was "not in favour of tax shelters".

The remarks have caused consternation among Britain's biotechnology industry. Paul Haycock of the Biotechnology Industry Association, described Dorrell's remarks as "very discouraging". Others said he was speaking out of turn, as the taxation of research is the responsibility of the British Treasury. 